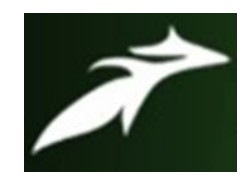

Kuldeep Kumar, International Journal of Advances in Agricultural Science \& Technology,

Vol.9 Issue.2, February-2022, pg. 1-5

ISSN: $2348-1358$

Impact Factor: 6.846

NAAS Rating: 3.77

\title{
Review of Various Sources of Nutrient Management on Maize (Zea mays) under Maize and Mungbean (Vigna radiata L.) Intercropping System
}

\author{
Kuldeep Kumar \\ Assistant Professor \\ Department of Agronomy, Kisan (P.G.) College, Simbhaoli (Ghaziabad), India \\ Email: - agronomy.kk@gmail.com; kkagri92@gmail.com
}

DOI: 10.47856/ijaast.2022.v09i02.001

\begin{abstract}
Experiment was conducted at Research Farm of Kisan (P.G.) College, Simbhaoli (Ghaziabad) during kharif seasons of 2020 and 2021. Fifteen treatment combinations consisting three cropping system viz. maize sole cropping, mung sole cropping and intercropping of maize and mung and five nutrient sources i.e. recommended doses of NPK (RDF). RDF + Farm Yard Marwure (FYM) 6t/h. RDF + Azospirillum" / Rhizobium. RDF + Phosphorus solubilizing bacteria and RDF- Farm Yard Manure (PYM)a Sub + Azospirillum Rhizobium + PSB were used in factorial RBD in four replications. Application of organic and biofertilisers over NPK increased the yield attributing characters and yield of maize. Highest yield attributing characters of maize was recorded with NPK+FYM A+P which ultimately resulted higher yield 29.67 and 32.22 q/ha during 2020 and 2021 respectively.
\end{abstract}

\section{INTRODUCTION}

Maize production in our country rose 9.80 million tones (with the target of 11.5 million tones) which was pretty close to target of 2.5 million tones. Maize with mung is more prominent intercropping prevails in major part of rainfed area of India. The success of the green revolution was the result of the introduction of high yielding varieties clubbed with better management practices adopted for higher productivity in the cereal crops. Now-a-days maize is also assuming importance in changing crop productivity, being a drought and disease resistant type with high grain number/cob. To increase the productivity under Indian conditions, efforts are being made to evolve high yielding, fertilizer responsive and non-lodging varieties. With this, the replenishment of soil nutrients began to involve extensive use of inorganic nitrogenous fertilizers, which are costly and are agents for water and air pollution too. Biofertilizers are coming as a better alternative to inorganic fertilizers. It is not the bacteria alone but the use of fungi, algae and fern is 


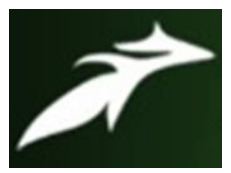

Kuldeep Kumar, International Journal of Advances in Agricultural Science \& Technology,

Vol.9 Issue.2, February-2022, pg. 1-5

ISSN: 2348-1358

Impact Factor: 6.846

NAAS Rating: 3.77

also getting predominance in increasing the productivity of different crops. For cereals, the use of nitrogen fixing bacteria such as Azospirillum also reported significant increase in grain yield of maize under field condition due to Azospirillum inoculation Only meager attempts have been made so far on the studies of maize and mungbean in pure and intercrop. Considering above fact the present study was undertaken to find out suitable source of nutrient management under sole as well as intercropping of maize and mung.

\section{MATERIALS AND METHODS}

The experiment was conducted at Research Farm of Kisan (P.G.) College, Simbhaoli (Ghaziabad) during kharif seasons of 2020 and 2021. The latitude and longitude of the farm's location are $29^{\circ} 46^{\prime}$ North and $772^{\circ} 59^{\prime}$ East, respectively. Elevation from mean sea level is 227.9 meters. Standard methods were used for soil analysis. Soil of experimental was loam in texture having $\mathrm{pH} 7.3$, organic carbon $0.35 \%$, available $\mathrm{N}$ $185.0 \mathrm{~kg} / \mathrm{ha}$, available P205 $20.8 \mathrm{~kg} / \mathrm{ha}$ and available $\mathrm{K} 20127.20 \mathrm{~kg} / \mathrm{ha}$. Fifteen treatment combinations consisting three cropping system viz. maize sole cropping, mung sole cropping and intercropping of maize and mung and five nutrient sources i.e. Recommended doses of NPK (RDF), RDF + Farm Yard Manure (FYM)@6t/h, RDF + Rhizobium**, RDF + Phosphorus solubilizing bacteria and RDF+ Farm Yard Manure (FYM)@6t/h + Azospirillum*/ Rhizobium+ PSB were used in factorial RBD in four replications. The crops were sown during last week of June to first week of July during both the year of experimentations. As per recommendation $120 \mathrm{~kg} \mathrm{~N}, 60 \mathrm{~kg} \mathrm{P} 205$ and $40 \mathrm{~kg} \mathrm{~K} 20$ per hectare was used for maize and $16 \mathrm{~kg} \mathrm{~N}$ and $40 \mathrm{~kg}$ P205 was used for mung. Maize crop was sown at $60 \mathrm{~cm}$ row spacing while mung was sown at $40 \mathrm{~cm}$. Varieties Kisan composite and Pusa Vaishali were used for maize and mung, respectively. Others standard package of practices were used for growing of both the crops.

\section{RESULTS AND DISCUSSION}

\section{Yield attributes}

Data presented in table 1, revealed that all the treatments significantly influenced all yield attributing characters except on grain wt per cob during both the years. Intercropping of maize mung bean recorded significantly higher yield attributing characters but it did not influence the grain wt. per cob (g) during both the years. Combined application of all the three sources of nutrients (FYM + Azospirillum + phosphorus solubilizing (bacteria) along with 'recommended dose of NPR recorded highest number of yield attributing characters which was significantly higher than recommended dose of fertilisers. Application of FYM. Azospirillum and PSB alone or in combination influenced the yield attributing characters significantly. This may be because of creating better nutritional environment for plant growth. 


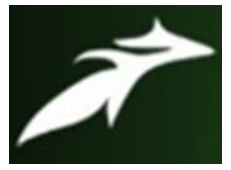

Kuldeep Kumar, International Journal of Advances in Agricultural Science \& Technology,

Vol.9 Issue.2, February-2022, pg. 1-5

ISSN: 2348-1358

Impact Factor: 6.846

NAAS Rating: 3.77

Table 1: Number of grains per cob, grain weight per cob and 1000 grain weight of maize as influenced by cropping and nutrient sources during 2020 and 2021

\begin{tabular}{|c|c|c|c|c|c|c|c|c|c|c|c|c|}
\hline \multirow{2}{*}{\begin{tabular}{l|} 
Treatment \\
Cropping systems
\end{tabular}} & \multicolumn{2}{|c|}{$\begin{array}{l}\text { Number of } \\
\text { cobs per } \\
\text { plant }\end{array}$} & \multicolumn{2}{|c|}{$\begin{array}{l}\text { Lenght of } \\
\text { cob }\end{array}$} & \multicolumn{2}{|c|}{$\begin{array}{l}\text { Diameter of } \\
\text { cob }(\mathrm{cm})\end{array}$} & \multicolumn{2}{|c|}{$\begin{array}{c}\text { Number of } \\
\text { grains } \\
\text { per cob }\end{array}$} & \multicolumn{2}{|c|}{$\begin{array}{l}\text { Grain weight } \\
\text { per cob (g) }\end{array}$} & \multicolumn{2}{|c|}{$\begin{array}{l}1000 \text { Grain } \\
\text { weight }(\mathrm{cm})\end{array}$} \\
\hline & & & & & & & & & & & & \\
\hline Sole & 1.20 & 1.20 & 21.70 & 22.72 & 5.40 & 6.20 & 362.7 & 394.8 & 52.00 & 52.70 & 223.0 & 227.9 \\
\hline $\begin{array}{l}\text { Intercropping } \\
\text { (Maize+Mung) }\end{array}$ & 1.20 & 1.23 & 21.94 & 22.95 & 5.67 & 6.40 & 380.7 & 414.3 & 52.16 & 54.61 & 230.8 & 235.2 \\
\hline $\mathrm{SEm} \pm$ & 0.01 & 0.01 & 0.02 & 0.02 & 0.01 & 0.01 & 5.55 & 6.45 & 0.47 & 0.55 & 0.40 & 0.43 \\
\hline CD5\% & 0.02 & 0.02 & 0.06 & 0.04 & 0.02 & 0.02 & 11.34 & 13.2 & NS & NS & 0.87 & 0.88 \\
\hline \multicolumn{13}{|l|}{ Nutreint sources } \\
\hline NPK & 1.12 & 1.17 & 20.50 & 21.60 & 4.86 & 5.55 & 335.4 & 363.9 & 51.24 & 52.11 & 222.6 & 227.4 \\
\hline$+\mathrm{FYM}(\mathrm{F})$ & 1.16 & 1.21 & 22.04 & 23.12 & 5.19 & 5.90 & 389.7 & 424.4 & 53.69 & 55.51 & 228.4 & 233.8 \\
\hline +Azospirillum (A & 1.19 & 1.23 & 22.68 & 23.70 & 5.42 & 6.37 & 372.6 & 406.4 & 52.10 & 53.51 & 226.7 & 232.0 \\
\hline$+\mathrm{PSB}(\mathrm{P})$ & 1.22 & 1.26 & 22.45 & 23.41 & 5.97 & 6.64 & 349.7 & \begin{tabular}{|l|}
377.9 \\
\end{tabular} & 51.46 & 52.56 & 225.4 & 230.7 \\
\hline$+\mathrm{F}+\mathrm{A}+\mathrm{P}$ & 1.26 & 1.32 & 24.11 & 25.01 & 7.27 & 7.14 & 410.1 & \begin{tabular}{|l|}
439.9 \\
\end{tabular} & 55.26 & 55.12 & 229.0 & 235.3 \\
\hline SEm \pm & 0.01 & 0.01 & 0.02 & 0.04 & 0.02 & 0.02 & 8.70 & 10.15 & 0.75 & 0.87 & 0.69 & 0.66 \\
\hline CD5\% & 0.03 & 0.03 & 0.06 & 0.07 & 0.03 & 0.03 & 18.90 & 21.87 & 1.59 & 1.86 & 1.44 & 1.49 \\
\hline
\end{tabular}




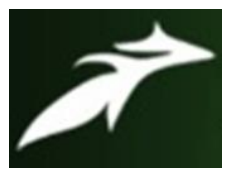

Kuldeep Kumar, International Journal of Advances in Agricultural Science \& Technology,

Vol.9 Issue.2, February-2022, pg. 1-5

ISSN: 2348-1358 Impact Factor: 6.846

NAAS Rating: 3.77

Table 2 : Grain, stover and biological yield and harvest index of maize as influenced by cropping and nutrient sources during 2020 and 2021

\begin{tabular}{|l|l|l|l|l|l|l|l|l|}
\hline Treatment & \multicolumn{2}{|l|}{$\begin{array}{l}\text { Grain yield } \\
(\mathbf{q} / \mathrm{h})\end{array}$} & $\begin{array}{l}\text { Stover yield } \\
(\mathrm{q} / \mathrm{h})\end{array}$ & \multicolumn{2}{l|}{$\begin{array}{l}\text { Biological } \\
\text { Yield (q/h) }\end{array}$} & \multicolumn{2}{l|}{ Harvest index } \\
\hline \multicolumn{7}{|l|}{ Cropping systems } \\
\hline Sole & 25.48 & 28.77 & 64.48 & 64.01 & 89.76 & 95.64 & 29.48 & 30.35 \\
\hline $\begin{array}{l}\text { Intercropping } \\
\text { (Maize+Mung) }\end{array}$ & 26.61 & 29.11 & 64.67 & 63.21 & 90.28 & 96.11 & 29.60 & 29.50 \\
\hline SEm \pm & 0.47 & 0.49 & 1.17 & 1.08 & 1.64 & 1.62 & 0.04 & 0.04 \\
\hline CD5\% & NS & NS & NS & NS & NS & NS & 0.07 & 0.08 \\
\hline Nutreint sources & & & & & & & & \\
\hline NPK & 24.30 & 26.62 & 60.77 & 60.73 & 85.90 & 91.80 & 29.50 & 30.36 \\
\hline +FYM(F) & 26.31 & 28.80 & 63.97 & 64.74 & 89.28 & 95.12 & 29.65 & 30.52 \\
\hline +Azospinillum(A & 25.21 & 28.59 & 63.77 & 64.14 & 88.87 & 94.73 & 29.57 & 30.44 \\
\hline +PSB (P) & 25.95 & 28.43 & 63.22 & 61.78 & 88.17 & 94.02 & 29.61 & 29.59 \\
\hline +F+A+P & 28.67 & 30.27 & 70.22 & 67.69 & 97.89 & 103.70 & 29.56 & 3.42 \\
\hline SEm \pm & 0.76 & 0.79 & 1.80 & 1.70 & 2.58 & 2.57 & 0.06 & 0.08 \\
\hline CD5\% & 1.50 & 1.55 & 3.80 & 3.54 & 5.30 & 5.29 & NS & NS \\
\hline
\end{tabular}




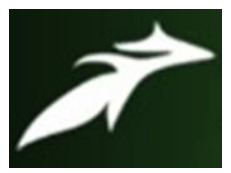

Kuldeep Kumar, International Journal of Advances in Agricultural Science \& Technology,

Vol.9 Issue.2, February-2022, pg. 1-5

ISSN: 2348-1358

Impact Factor: 6.846

NAAS Rating: 3.77

\section{CONCLUSION}

Perusal of data given in table 2 revealed that intercropping of maize mung bean did not influence the grain yield, stover yield and biological yield of maize during both the years. Harvest index was significantly influenced by intercropping during both the years. Nutrient sources significantly influenced the grain yield of maize but harvest index was not influenced by the nutrient management during both the years of experimentations. Recommended dose of fertilisers along with FYM+PSB+ Azospirillum recorded significantly highest grain yield, stover yield, biological yield and harvest index of maize over NPK i.e. RDF during both the .4years. Supplementation of RDF through organic and biological source of nutrition increases the yield of maize during both the years. Individual application of nutrient source over RDF increases the grain yield of maize but the difference was not significant. This may be attributed due to provide better nutrition to the crops resulted higher yield attributes and ultimately yield of maize.

On the basis of above study it has been observed that growing of maize with mung as inter-crop is more suitable than sole cropping Supplementation of RD suitable than sole cropping. Supplementation of RDF though FYM, PSB, Azospirillum alone or in combination was found more beneficial. Combined application of RDF+FYM+Azospirillum +PSB recorded higher yield and can be recommended for maize and mung intercrop cultivation.

\section{REFERENCES}

[1]. Brar B.S; Dhillon, N.S. and Chhina, H.S. (2001). Integrated use of farm yard manure and inorganic fertilizers in maize. J. Agric. Sci. 71 (9): 605-607.

[2]. Hirota ; Hashem, A. and Hamid, A. (1995). Yield, photosynthesis and canopy structure of maize- mungbean intercropping system. Japanese J. Tropical Agric. 39 (3): 168-176.

[3]. Laxminarayana, K. (2001). Effect of Azotobacter and Azospirillum on yield performance of maize in hilly regions of Mizoram. Indian J. Hill Farming 14 (2): 134-137.

[4]. Rai, R.K.; Sinha, M.N. and Singh M (1982). Studies on direct and residual effect of phosphorus on growth and yield of maize and wheat in square. Indian J. Agron. 27 (4): 354-364. 